\title{
Geopolitics, Ethnic Politics along the Border, and Chinese Foreign Policy Changes toward Myanmar
}

\section{Enze Han, Department of Politics and International Studies, SOAS University of London}

\section{Introduction}

China's dramatic rise in power and the United States' rebalancing to the Asia Pacific region for the past few years have drawn heightened interest in what China's rise means

for regional order. ${ }^{1}$ Specifically, how China handles its relations with neighboring states in the region, and how such states respond to China's rise, has come under increasing scrutiny. ${ }^{2}$ One such case is China's relations with Myanmar ${ }^{3}$, which have undergone significant changes recently. As a result of Myanmar's domestic political liberalization and normalization of relations with the West, especially the United States, since 2011, Myanmar has made noteworthy efforts to move away from its erstwhile dependence on China. Facing international isolation and sanctions during the military governments the State Law and Order Restoration Council (SLORC) (1988-1997) and the State Peace and Development Council (SPDC) (1997-2010), Myanmar did not have much leeway in bargaining with Beijing, while the latter provided needed diplomatic protection and economic investment. However, such dependence created a situation where Myanmar perceived China's preponderate position in its foreign relations as detrimental to its 
This is the version of the article accepted for publication in Asian Security published by Taylor \& Francis: http://www.tandfonline.com/loi/fasi20

Accepted version downloaded from SOAS Research Online: https://eprints.soas.ac.uk/23597/

national interests. By reorienting its foreign relations to balance against China, Myanmar has significantly improved its bargaining position toward China, which manifests in its newfound ability to push back against China's economic and strategic penetration into the country. Especially in the context of the renewed American strategic rebalancing to the Asia Pacific region, China now faces substantial competition in its dealings with Myanmar, and much of its economic and strategic interests in the country now face tremendous uncertainty.

The uncertainty surrounding Myanmar's foreign policy reorientation has created a dilemma for China in how best to handle the challenges it faces. China has tried a proactive diplomatic overture toward Myanmar, both to smooth tested bilateral relations and express its displeasure while demonstrating its crucial value to the Myanmar government. ${ }^{4}$ However, the strategic competition with the United States in Southeast Asia also does not give much freedom of movement for the Beijing government. On one hand, Beijing had the need to protect its existing interest in Myanmar from further erosion, or at least to maintain its advantageous position within the strategically important border area between the two countries, given the huge amount of investment on several major projects have already in place, such as the oil and gas pipelines. ${ }^{5}$ On the other hand, Beijing also would like to remind Myanmar the great leverage China holds over various ethnic rebel groups operating along the Sino-Myanmar border area. The trick is to find a foreign policy approach toward Myanmar that can balance the two.

This paper presented an analysis of China's changing foreign policy behaviors toward Myanmar, using the theoretical prism of how great powers react to hedging strategies 
This is the version of the article accepted for publication in Asian Security published by Taylor \& Francis: http://www.tandfonline.com/loi/fasi20

Accepted version downloaded from SOAS Research Online: https://eprints.soas.ac.uk/23597/

practiced by middle or small powers. It argues that the strategic uncertainty created by the sudden changes in Myanmar's foreign policy orientation prompted the need for Beijing to effectively communicate its displeasure as well as to demonstrate its determination to protect China's national interests to the Myanmar government. It argues Beijing strategically utilized domestic nationalism as foreign policy signal to showcase its resolve with regard to its concern of border security between the two countries. By allowing domestic nationalist sentiment toward Myanmar to build, the Chinese government effectively bound itself to act tough toward its southern neighbor.

To demonstrate the logic of the argument, this paper focuses on a set of militarized ethnic clashes along the Sino-Myanmar border area as comparative case studies. It examines the three armed conflicts between Myanmar's central government and the ethnic-Kokang Myanmar National Democratic Alliance Army (MNDAA) in 2009 and 2015, as well as conflicts with the Kachin Independence Army (KIA) between 2011-2013, and compares the respective responses given by the Chinese government. Because the three conflicts occurred before, during, and after Myanmar's foreign policy shifts, the timing of these events and the divergent responses they received thus provide an excellent lens to examine how changes in China's foreign policy approaches to its southern neighbor have evolved. Additionally, the Kokang and Kachin ethnic groups in Myanmar differ significantly in that the former is ethnically Han Chinese - the majority ethnic group in China - and has the potential to enlist nationalist response from Chinese public as an issue of how overseas Chinese being treated in Southeast Asia. The Kachin only has ethnic kinship ties with Jingpo, which is itself a small ethnic minority group in China, that's why the conflict remain distant from the Chinese nationalist public. Indeed, during 
This is the version of the article accepted for publication in Asian Security published by Taylor \& Francis: http://www.tandfonline.com/loi/fasi20

Accepted version downloaded from SOAS Research Online: https://eprints.soas.ac.uk/23597/

the second Kokang conflict in 2015, domestic nationalist sentiment toward Myanmar built up, which was utilized by the Chinese government to pressure the latter.

This paper thus represents an attempt to understand the recent changing bilateral relations between Myanmar and China through a relatively controlled analysis focusing on a common issue of ethnic conflict along the borderland. ${ }^{6}$ The structure of the paper is as follows. The paper first introduces the theoretical framework to understand Chinese foreign policy behavior changes. It then proceeds to a short background introduction of the bilateral relations between China and Myanmar during the modern period, as well as the most recent geopolitical competition between the U.S. and China in Southeast Asia and its implications for Myanmar's foreign policy reorientation. The paper then offers a detailed analysis of the three militarized conflicts. In each case study, it presents Chinese government's responses by analyzing official Chinese foreign ministry statements as well as China's domestic media coverage. It then scrutinizes the differences in the Chinese responses within the context of its overall diplomatic overture toward Myanmar before and after the latter's foreign policy reorientation. Highlighting the issue of overseas Chinese (haiwai huaren) in China's foreign policy, the paper concludes that we need to understand China's changed approach to Myanmar through a combined lens of geopolitical changes in the region and the role domestic nationalism plays in Chinese foreign policy making.

\section{Theoretical Framework}

The United States' strategic competition with China for primacy in the Asian Pacific region has gained tremendous amount of scholarly attention during the past few years. 
This is the version of the article accepted for publication in Asian Security published by Taylor \& Francis: http://www.tandfonline.com/loi/fasi20

Accepted version downloaded from SOAS Research Online: https://eprints.soas.ac.uk/23597/

Inspired by the literature on smaller states' foreign relations ${ }^{7}$, many people are now interested in how smaller states in the region respond to the changing power balance between the two great powers. For example, many have put forward the concept of hedging to explain several Southeast Asian states' foreign policy options in the context of U.S.-China strategic competition. Instead of the dichotomous choices of balancing or bandwagoning, increasingly scholars have noticed that many Southeast Asian states have tried to engage with two great powers without necessarily committing to either one. ${ }^{8}$ Differentiable from balancing and bandwagoning, hedging by smaller states entail the use of an ambiguous positioning with mixed signals to both great powers, and approach both with selective deployment of power acceptance and power rejection. ${ }^{9}$

However, how China responds to such hedging activities by smaller states in Southeast Asia is worth exploring. Specifically, we want to understand how China views its interests in Southeast Asia and how they should be protected or promoted given the intensification of competition from the United States. Especially in situations of uncertainty, such as when Myanmar's government started its political transition in 2010 and began a rapid diplomatic rapprochement with the West, how China handles such changes is demonstrative of its general foreign policy strategies. Indeed, recent literature on Chinese nationalism and foreign policy argues that the Chinese government often allows certain nationalist expressions, such as not censoring online debates or allowing protests, as signals toward foreign governments. ${ }^{10}$ For example, Jessica Weiss argues that “[B]y tolerating nationalist protests, authoritarian leaders reveal the status quo's vulnerability to popular upset," which indicates, in the case of the Chinese government, 
This is the version of the article accepted for publication in Asian Security published by Taylor \& Francis: http://www.tandfonline.com/loi/fasi20

Accepted version downloaded from SOAS Research Online: https://eprints.soas.ac.uk/23597/

its "incentive to stand firm and risk an international standoff rather than face the wrath of mobs at the palace gates."11

Yet, previously most such popular nationalism in China targets at Japan, the United States or the West, which is due to the history of humiliation under the hands of the Japanese or the Western imperial powers, and the fact that the Chinese government has consistently emphasized them in its patriotic education and nationalist propaganda. Nonetheless, China's relationship with a country like Myanmar does not have such nationalist baggage. In its stead, there is the issue of overseas Chinese, which exist in large quantity in Myanmar as well as most Southeast Asian countries, which does serve as a potential nationalist item because of the Chinese state's increasingly sensitive reaction to how its diaspora are treated. This paper thus engages this focus on the role of nationalism in Chinese foreign policy, and examines how it manifest in Beijing's changing diplomatic relations with its southern neighbor.

\section{Background of Sino-Myanmar Relations}

When the People's Republic of China (PRC) was founded, the new communist government faced a hostile international environment, with diplomatic recognitions from non-communist countries slow in coming. Myanmar was one of the first non-communist countries to recognize the PRC, and the Yangon government coined the term paukphaw ${ }^{12}$ to describe bilateral relations. Particularly, 'Myanmar's leaders were worried the PRC might interfere in their internal affairs because of the disparities in power and the geographical proximity of the two countries. ${ }^{13}$ In the early 1950 s, there were legitimate reasons for the Yangon government to fear Beijing's intentions in Myanmar, particularly 
This is the version of the article accepted for publication in Asian Security published by Taylor \& Francis: http://www.tandfonline.com/loi/fasi20

Accepted version downloaded from SOAS Research Online: https://eprints.soas.ac.uk/23597/

with regard to the Burmese Communist Party $(\mathrm{BCP})$ and its relations with the Chinese Communist Party (CCP), as well as the incursion of the Chinese Nationalist (KMT) army into Myanmar's Shan states as a result of its loss in the Chinese civil war. ${ }^{14}$

On the issue of the BCP, Yangon had strong suspicion from the very beginning of the Chinese Communist Party's (CCP) involvement, although the CCP did not provide the BCP much overt support in the early 1950s, thanks to the U Nu government's friendly gestures toward Beijing. ${ }^{15}$ Most worrisome for the Myanmar government, however, was the KMT's incursion into the Shan states, leading to fears that the People's Liberation Army (PLA) might invade Myanmar to eliminate KMT forces supported by the U.S. and Thai governments. ${ }^{16}$ Because of those concerns, Yangon treaded carefully so as not to do anything that might incur Beijing's intervention. In the aftermath of the Korean War, when the PRC emerged from the 1954 Geneva Conference more confident in its international diplomacy, Myanmar and China agreed on the "Five Principles of Peaceful Coexistence" in June 1954, which indicated "China's public assurance that it would not interfere in Myanmar's internal affairs." ${ }^{\prime 17}$ Through Myanmar's pledge that it would pursue a strict neutralist foreign policy and not be a "stooge" for imperial powers, Beijing showed significant understanding and restraint regarding the KMT issue and pretty much allowed Myanmar's military (Tatmadaw) to take care of the issue itself. Later, in the early 1960s, the PLA and Tatmadaw to push the remaining KMT forces out of Myanmar. ${ }^{18}$ In 1960, Myanmar and China also peacefully demarcated the border between the two countries, with the PRC allegedly making more concessions. 
This is the version of the article accepted for publication in Asian Security published by Taylor \& Francis: http://www.tandfonline.com/loi/fasi20

Accepted version downloaded from SOAS Research Online: https://eprints.soas.ac.uk/23597/

However, during the Cultural Revolution, Beijing decided to export radicalism to Myanmar's sizable overseas Chinese community, which sparked anti-Chinese riots in 1967 in several major cities. ${ }^{19}$ In the aftermath of the riots, Beijing cut off bilateral relations, and started to overtly support the BCP's armed struggle. ${ }^{20}$ The CCP provided financial, military, and even personnel support for the BCP to establish more than 20,000 square kilometers along the Sino-Myanmar border as a "liberated area."21 Weapons and military advisors were dispatched to the BCP-occupied area. China also gave CNY 2 million per year to the $\mathrm{BCP}$ for general military expenditures and opened hospitals along the border for the BCP's use. Beijing also helped set up a radio station, Voice of Burmese People, for the BCP to disseminate propaganda. ${ }^{22}$ The Chinese support for the BCP only started to dwindle down in the mid-1980s, which finally led to the demise of the BCP in 1989. However, the legacies of the BCP militarization continued, as ethnic rebels carved up various autonomous "special regions" in Shan and Kachin states. Even though many of these rebel groups signed ceasefire agreements with the Myanmar government in the 1990s, many still manage their internal administration without much interference from the central government. In fact, the rebel groups' continued militarization has made them targets for eventual elimination, thereby providing the background story for the three militarized clashes that will be discussed in detail below. ${ }^{23}$

Immediately after suppressing China's anti-government democratic movement in 1989, and with the SLORC's own suppression of the 88 student movement the year before, Beijing formally expressed its principle of non-interference in Myanmar's internal affairs, refraining from criticizing Myanmar's domestic policies while providing much-needed diplomatic support. ${ }^{24}$ Most significantly, after the 2003 Depayin incident ${ }^{25}$, China helped 
This is the version of the article accepted for publication in Asian Security published by Taylor \& Francis: http://www.tandfonline.com/loi/fasi20

Accepted version downloaded from SOAS Research Online: https://eprints.soas.ac.uk/23597/

shield the military government from punitive actions from the West, joining with Russia to veto a 2007 United Nations Security Council Resolution against Myanmar sponsored by the U.S. and U.K. Additionally, the Western governments have also imposed stringent sanctions on Myanmar, ${ }^{26}$ but such sanctions arguably did not achieve intended goal of regime change in Myanmar, primarily because the U.S. and other Western countries could not cut Myanmar off entirely from trading with other nearby nations. ${ }^{27}$ In fact, such sanctions rather redirected Myanmar's trade to its immediate neighbors in East, Southeast, and South Asia, resulting in increased trade with China, Thailand, Singapore, South Korea and Malaysia. ${ }^{28}$

In 2009 and 2010, China's trade surplus with Myanmar was USD 3.7 billion, while in 1989 the bilateral trade volume was only USD 313.72 million. ${ }^{29}$ By 2011 , China became Myanmar's second-largest trading partner after Thailand, also emerging as its top investor, with heavy concentration in the hydropower and mining sectors. Particularly, in 2009 Myanmar and China agreed to construct a USD 1.5 billion crude oil pipeline and a USD 1.04 billion natural gas pipeline to connect the Indian Ocean port of Kyaukphyu to Kunming, Yunnan province. ${ }^{30}$ These two pipelines are crucial to China's energy security because they allow China to get around the Strait of Malacca for its energy supplies. This represents the general geostrategic design where China hopes to have access to the Indian Ocean via Myanmar. By acquiring access to these two pipelines, China has gained tremendous amount of strategic access in Myanmar. ${ }^{31}$

\section{Chinese Interests in Myanmar under Threat}


This is the version of the article accepted for publication in Asian Security published by Taylor \& Francis: http://www.tandfonline.com/loi/fasi20

Accepted version downloaded from SOAS Research Online: https://eprints.soas.ac.uk/23597/

Myanmar began perceiving China's presence in the country as overbearing, which propelled Naypyidaw $^{32}$ to seek better relations with the West, particularly the United States, to balance against China. ${ }^{33}$ After the 2010 election, the new president, Thein Sein, to the surprise of many, initiated several major domestic political reforms, while at the same time normalizing relations with the West. In December 2011, Hillary Clinton became the first U.S. secretary of state to visit Myanmar since 1955, and President Barack Obama made history as the first U.S. president to visit Myanmar 11 months later, visiting again in 2014. All these overtures by the Americans fit right in with the overall geostrategic rebalancing to the Asia Pacific region, thus heightening competition between the U.S. and China in Southeast Asia.

The geostrategic competition between the U.S. and China has offered Myanmar more capacity to push back against China's position in the country. At the same time, Myanmar's domestic political transition opened up space that enabled interest groups opposing Chinese investment in the country to mobilize. Many also took advantage of the newly available freedom of speech to criticize the Chinese government because of its past support of the military junta. As a result of a congruence of these factors, many of China's investment projects came under significant public and official pressure. In September 2011 President Thein Sein announced the suspension of construction work on the Myitsone Dam, which the China Power Investment Corporation (CPI) built to produce electricity for Chinese consumption. Similarly, China's investment in the Letpadaung Copper Mine has also faced tremendous popular criticism and resistance. Most recently, China's plan for building rail lines linking Yunnan to the Indian Ocean has also been shelved due to the lack of interests from Myanmar. ${ }^{34}$ All this pressure has 
This is the version of the article accepted for publication in Asian Security published by Taylor \& Francis: http://www.tandfonline.com/loi/fasi20

Accepted version downloaded from SOAS Research Online: https://eprints.soas.ac.uk/23597/

made China anxious about its existing investment in Myanmar, which also underlies the dilemmas about how to respond.

Myanmar's rapid political changes and foreign policy shift toward the West caught China off guard. The previous perception of Myanmar as "loyal" ally and as a relatively secure strategic "backyard" does not hold any longer. Rather, the U.S.'s diplomatic overture to Myanmar has generated tremendous anxiety over the U.S.'s strategic design in Myanmar and led to palpable fear of further U.S. containment of China along its previously "safe" southwestern border. Despite the U.S.' constant reassurances that it does not intend to contain China and its diplomatic overtures toward Myanmar are not about China, many in China see it merely as cheap diplomatic rhetoric. Beijing has interpreted the increased U.S. presence in Myanmar as a potential threat to China's Indian Ocean access, its oil and gas pipelines and even its border security, especially when the U.S. started trying to get involved in the Kachin peace negotiation process (more on this later). ${ }^{35}$

Furthermore, the Myanmar government's improved bargaining position in relation to Beijing means Naypyidaw can say "no" more easily than before, as the suspension of the Myitsone Dam project shows. Now China is increasingly worried that many of its investment projects negotiated with the previous military government might be in jeopardy of renegotiation of terms or cancelation due to domestic anti-Chinese sentiment. Anti-Chinese sentiment was prevalent before, but the military government was perhaps more willing to dampen it through media censorship due to its dependence on China. Now, however, the liberalized domestic political environment and Western backing 
This is the version of the article accepted for publication in Asian Security published by Taylor \& Francis: http://www.tandfonline.com/loi/fasi20

Accepted version downloaded from SOAS Research Online: https://eprints.soas.ac.uk/23597/

means anti-Chinese sentiment can effectively be utilized for political mobilization, and Myanmar can use those anti-Chinese sentiments to put pressure on China.

Hence, China has found itself in a very awkward position. On the one hand, there has been significant anger in Beijing and Yunnan about the Myanmar government's "betrayal," creating a strong impression of Myanmar as "untrustworthy." 36 Particularly with regard to the suspended Myitsone Dam project, from the Chinese perspective, it was Myanmar that breached the contract, and the CPI has suffered significant financial losses as a result because Myanmar doesn’t seem to want to give it financial compensation, citing a lack of transparency in negotiations of the agreement with the previous military government. ${ }^{37}$ However, it seems there is not much China can do to make Naypyidaw comply with its demands. Retaliation against Myanmar runs the risk of pushing Myanmar further into the embrace of the West, which obviously is not in China's interest. Furthermore, China's heavy investments in hard infrastructure, such as the two pipelines, means it is more beholden to the Myanmar government's policies. The financial stakes with these two pipelines are extremely high, so in China's own calculation they drastically overweigh the setbacks in the Myisone Dam project for example, as currently the priority for Beijing is to maintain as much as it can its existing access to Myanmar without losing too much ground to Western and Japanese, competitors. How to respond to the changing situation in Myanmar thus poses a significant challenge for Beijing. It requires a proactive engagement with the Myanmar government, but it also needs to communicate its resolve on issues it deems as pertinent to China's national interests, which it hopes Naypyidaw would respect. 
This is the version of the article accepted for publication in Asian Security published by Taylor \& Francis: http://www.tandfonline.com/loi/fasi20

Accepted version downloaded from SOAS Research Online: https://eprints.soas.ac.uk/23597/

\section{Three Militarized Conflicts along the Border and China's Responses}

It is within this changing geostrategic context that this paper focuses on three militarized conflicts between the Myanmar central government and two ethnic rebel groups along the Sino-Myanmar border region in order to demonstrate the pattern of transformation in the Chinese government's foreign policy approach toward Myanmar. The first one is the armed conflict in Kokang in August 2009 between Myanmar central government forces and the MNDAA; the second conflict was with the Kachin Independence Army from 2011 to 2013; and the last one was with the Kokang again from February to May 2015. In all three bombs landed on the Chinese side of the border, twice causing Chinese casualties. The timings of three conflicts make the comparison extremely useful for our focus on the geostrategic change and Myanmar's foreign policy reorientation. The first one occurred when Myanmar remained heavily dependent on China's diplomatic protection and when China considered its presence secure with a friendly government in power; while the other two occurred in the aftermath of Myanmar's foreign policy reorientation and active engagement with the West, particularly the United States. Furthermore, the Kachin and the Kokang conflicts differ in that the latter involves ethnic Han Chinese people in Myanmar while the former only involves the Kachin, whose kin in China are known as the Jingpo ethnic minority. The following texts analyze the three militarized conflicts and the different responses they received from the Chinese government. With the changing circumstances of Myanmar's foreign policy orientation, would we observe noticeable changes in the Chinese government's response to Myanmar? 
This is the version of the article accepted for publication in Asian Security published by Taylor \& Francis: http://www.tandfonline.com/loi/fasi20

Accepted version downloaded from SOAS Research Online: https://eprints.soas.ac.uk/23597/

Kokang Conflict 2009

The Kokang are an ethnic group in Myanmar of Chinese origin. Many speak the dialect of Mandarin spoken across the border in Yunnan province, and their origin myth often claims they are descendants of Ming Dynasty troops who fled China into Myanmar after the Manchu took over China and founded the Qing Dynasty. The current MNDAA came about as an offshoot of the BCP after that organization collapsed in 1989. In 1989, the MNDAA, under the leadership of Peng Jiasheng, signed a ceasefire with the military government, and the Kokang region became "Special Region 1" of northern Shan states. Before the ceasefire was broken, in 2009, the Kokang area was implicated in drug trafficking, as well as illegal gambling and prostitution catering to Chinese tourists across the border.

Just as the ceasefire agreements that many other rebel groups signed with the central government did not lead to the groups laying down arms, the MNDAA in fact had de facto autonomy in running its own affairs, and its military is not subordinate to the Myanmar military. However, since 2008, the Myanmar central government has proposed incorporating the ethnic rebel armies into its own national "border guards," which several armed groups rejected as designed to disarm them. The first target that the Myanmar government picked was the Kokang, a relatively small force that was no match for the central government's military. The conflict lasted throughout August 2009, and by the end of the month the Myanmar central government had overrun the MNDAA, while a faction of it also defected to the government side. Peng was thus ousted and went into hiding. Although the conflict was relatively small in scale, a reported 37,000 refugees 
This is the version of the article accepted for publication in Asian Security published by Taylor \& Francis: http://www.tandfonline.com/loi/fasi20

Accepted version downloaded from SOAS Research Online: https://eprints.soas.ac.uk/23597/

crossed the border into China, although many of them are Chinese citizens who work in Kokang. ${ }^{38}$ Also during the conflict, a bomb landed on the Chinese side of the border, killing one civilian. ${ }^{39}$

On 1 September 2009 at the Chinese MOFA spokesperson media briefing, a journalist asked whether China was worried about the border security between China and Myanmar, when the refugee camps for the Kokang conflict would be closed, and whether China would ask the refugees to leave. MOFA spokesperson Jiang Yu replied that "China and Myanmar are friendly neighbors, and we want to see that Myanmar maintains peace, stability and development...we want to see the situation along the border quickly return to stability and for the refugees to return home soon." ${ }^{40}$ In response to another journalist's question of whether China provided help for the refugees, she answered, "The Yunnan provincial government has taken active measures and settled more than 10,000 Myanmar refugees...However, I want to emphasize that maintaining stability along the border suits the fundamental interest of people in both countries and is both governments' mutual responsibility. We hope Myanmar properly resolve its domestic issues and take necessary measures to return the situation on the border to normal, as well as guaranteeing the security of Chinese people and property in Myanmar." ${ }^{41}$ From the way the Chinese government handled the 2009 Kokang conflict, it seems Beijing essentially let Myanmar deal with it by itself, and China was not willing to get involved. Such a hands-off approach at the time represents the perception in Beijing that the Myanmar government was a friendly neighbor and that it could rely on Myanmar protecting Chinese interests in the country. 
This is the version of the article accepted for publication in Asian Security published by Taylor \& Francis: http://www.tandfonline.com/loi/fasi20

Accepted version downloaded from SOAS Research Online: https://eprints.soas.ac.uk/23597/

Kachin Conflict 2011-2013

The Kachin are one of the main ethnic minority groups in Myanmar, and the Kachin state used to be part of the Frontier Areas during the British colonial period that was governed separately from Ministerial Burma. ${ }^{42}$ In China, the Kachin are categorized as the Jingpo, one the country's 55 officially recognized ethnic minority groups. ${ }^{43}$ Also during the colonial era, the British heavily recruited Kachin soldiers for the colonial army. After Myanmar gained its independence in 1948, the Kachin faced reprisal for their role during the colonial period, while at the same time coming under repression by the government, under the control of the majority Bamar ethnic group. In 1962, after Ne Win abolished the Union of Burma constitution, Kachin forces withdrew to form the KIA, with the Kachin Independence Organization (KIO) as its political wing. ${ }^{44}$ In 1994, the KIA signed a ceasefire with the Myanmar central government, which lasted until $2011{ }^{45}$

After the Myanmar central government took out the Kokang in 2009, its attention shifted toward KIA, which also refused to be disarmed and become border guards. Fighting started in June 2011 and lasted sporadically into 2013, when ceasefire talks started again. Fighting intensified in December 2012 and January 2013, when the Myanmar military made heavy use of airstrikes and artillery against KIA positions around the rebels' headquarters in Laiza. ${ }^{46}$ However, in contrast to the easy success with the Kokang, the Myanmar central military could not take down the KIA as the rebels maintained their control around Laiza. Because of the close proximity of Laiza to the Chinese border, several bombs also landed on the Chinese side. As a result of the fighting, thousands of Kachin refugees also crossed the border into China. ${ }^{47}$ 
This is the version of the article accepted for publication in Asian Security published by Taylor \& Francis: http://www.tandfonline.com/loi/fasi20

Accepted version downloaded from SOAS Research Online: https://eprints.soas.ac.uk/23597/

The Kachin conflict occurred during the time when China's perception of friendliness on the part of the Myanmar government changed after the latter's foreign policy reorientation. The shift resulted in a more proactive response from China toward the situation in Myanmar, as we can see from the different approach China took regarding the Kachin conflict in 2013. On 4 January 2013, at the MOFA briefing, a reporter asked about the Chinese government's position on Myanmar's military actions against the KIA, and how it would respond to the bombs that landed on the Chinese side of the border. MOFA spokeswoman Hua Chunying replied, "During the military clash between Myanmar government forces and the KIA, three bombs landed on Chinese territory but didn't lead to casualties. China has raised its concerns with Myanmar, demanding that Myanmar take immediate measures to avoid such incidents in the future. Problems in northern Myanmar are Myanmar's internal affairs. China hopes the Myanmar government can solve its problems through peaceful dialogue with the relevant parties and maintain peace and stability in the borderland area." ${ }^{48}$ However, in the following weeks it seemed the Myanmar government did not heed the Chinese government's concerns, instead escalating its military conflict with the KIA, and bombs continued falling on China's side of the border. On 17 January 2013, when asked about the ongoing conflict, MOFA spokesman Hong Lei expressed strong discontentment toward Myanmar. He said, "China has lodged an urgent complaint to Myanmar, expressed its severe concern and displeasure at the situation, and demanded that Myanmar carry out sincere investigations and take all necessary measures to prevent such incidents from occurring again. China calls for the conflicting parties to show the utmost restraint, reach a ceasefire immediately and resolve their differences through dialogue." ${ }^{49}$ 
This is the version of the article accepted for publication in Asian Security published by Taylor \& Francis: http://www.tandfonline.com/loi/fasi20

Accepted version downloaded from SOAS Research Online: https://eprints.soas.ac.uk/23597/

It seemed that by this point, the Chinese government started to sense a need to become more actively involved in the conflict between the Myanmar government and the KIA, and it started to pressure both sides to negotiate. On 21 January 2013, the MOFA confirmed that that "Recently, the Chinese government special envoy, MOFA Vice Minister Fu Ying, visited Myanmar, and both sides reaffirmed they would maintain peace and stability in the borderland area between China and Myanmar....We think the only right way to solve the problem in northern Myanmar is through peace negotiations, and we hope the fighting parties can reach a ceasefire and begin talks. China will continue its contrastive role to maintain peace and stability along the border." ${ }^{, 50}$

Indeed, after two weeks of Chinese pressure, the Myanmar government and the KIA agreed to sit down for peace talks. The first round happened on 4 February in Ruili, Yunnan province, with another round on 11 March in the same city. Also, during this period, China appointed Ambassador Wang Yingfan as special envoy for Asian Affairs, but his primary responsibility was to oversee the peace negotiations and other developments in Myanmar. And in fact, during this round of negotiations, various parties, especially the KIA, considered China's approach overbearing. ${ }^{51}$ This subsequently led to the next round relocating back to Myitkyina, the Kachin State capital. The Chinese government decided to get more directly involved partly because it was concerned about the involvement of the US and UK in the peace-negotiation process (the KIO and the Myanmar government sent invitations to the US and UK governments to send representatives to the negotiation table). China, however, was firmly against the "internationalization" of the Kachin conflict. The idea that the US might get closer access to its southwestern border made China more willing to act proactively in handling the 
This is the version of the article accepted for publication in Asian Security published by Taylor \& Francis: http://www.tandfonline.com/loi/fasi20

Accepted version downloaded from SOAS Research Online: https://eprints.soas.ac.uk/23597/

Kachin peace negotiation process. In the end, over China's objections, a comprised solution was that the UN was invited to send a representative to the round of peace negotiations held in May 2013.

The Kachin conflict thus became the first instance where the Chinese government was actively involved in rounds of peace negotiations between the Myanmar government and an ethnic rebel group. This certainly represents a departure from the conventional emphasis the Chinese government places on "non-intervention in other countries' domestic affairs" in its foreign policy. Viewed within the context of China's general anxiety toward Myanmar's foreign relations with the West and domestic political changes, it is understandable for Beijing to demonstrate to Naypyidaw the crucial position and power it wields in the borderland area.

\section{Kokang Conflict 2015 \& Peng's Open Letter to the Chinese People}

After Peng Jiasheng went into hiding following the MNDAA's defeat, six years passed with relative peace in Kokang, which became a self-administered zone under the control of the Myanmar central government. However, fighting erupted again in Kokang when Peng came back with his troops, supported by several other ethnic rebel armies. ${ }^{52}$ In February 2015, MNDAA attached Myanmar government posts around Laojie, the capital city of Kokang. Fighting lasted until May, when the Myanmar government seized the last stronghold of MNDAA. ${ }^{53}$ During the conflict, an estimated number of 40,000 to 50,000 civilians fled from the Kokang region to China. 
This is the version of the article accepted for publication in Asian Security published by Taylor \& Francis: http://www.tandfonline.com/loi/fasi20

Accepted version downloaded from SOAS Research Online: https://eprints.soas.ac.uk/23597/

A few days after Peng and his MNDAA troops attacked Myanmar government posts in Laojie, an open letter allegedly written by Peng appeared on the Internet addressing Chinese people around the world. ${ }^{54}$ Written in Chinese, the letter used sentimental language detailing the tragedy of the Kokang people at the hands of the Myanmar government and emphasized the ethnic connection between the Kokang people and the Chinese people in a plea for support. For example, he stated that the Kokang are Chinese people and used to be part of China, blaming the severance of Kokang from China on imperialism because it was British encroachment on China's territory since the Opium War that led Kokang to be ceded to British Burma in 1897. He then called upon all Chinese people to support the Kokang, especially at a time when the People's Republic of China (PRC) was reclaiming its great power status.

Such open letters to the whole Chinese nation have historically not been a very common practice, and the effect of Peng's letter, especially in Chinese-language media, was electrifying. Angry Chinese nationalists bemoaned the Chinese government for being weak and called for tough action against Myanmar. Chinese domestic media followed up with interviews of Peng, and many carried long stories about Kokang's history, and the past and present conflict between the MNDAA and the Myanmar central government. Then, in early March, Chinese domestic reports started to emerge about Myanmar's bombs landing on the Chinese side of the border, which led Chinese foreign ministry spokesperson Hong Lei to express the Chinese government's desire that Myanmar prevent further such occurrences. ${ }^{55}$ On 13 March, bombs from an airstrike by the Myanmar military landed on the Chinese side of the border, killing five Chinese nationals and injuring nine. ${ }^{56}$ The killing of Chinese citizens by an allegedly "stray" bomb from 
This is the version of the article accepted for publication in Asian Security published by Taylor \& Francis: http://www.tandfonline.com/loi/fasi20

Accepted version downloaded from SOAS Research Online: https://eprints.soas.ac.uk/23597/

Myanmar significantly fired up the nationalist netizens. Many expressed anger at the "little country" Myanmar daring to bomb Chinese territory, leading to the deaths of Chinese citizens. Many also ridiculed the Chinese government, calling out its incompetency to protect its sovereignty despite its "self-claimed" big power status. Most, however, strongly called upon the Chinese government to take punitive action against Myanmar. Some even compared the Kokang situation to Crimea, and stated that it was time for China to learn from Russia's example in protecting its co-ethnics abroad. That rhetoric prompted the government-affiliated Global Times to publish an editorial rejecting the comparison, emphasizing that the Kokang, even though they are ethnic Chinese, are not Chinese citizens. ${ }^{57}$

It is within this context that we observe the totally different response the Chinese government took toward the 2015 Kokang conflict versus the one in 2009. After reports emerged that Chinese civilians died as a result of stray bombs from Myanmar, MOFA spokesman Hong Lei said in a 16 March 2015 media briefing, "China has lodged a strong complaint to Myanmar. Myanmar has expressed its sorrow for the Chinese casualties and will investigate and properly handle the issue. Myanmar has also sent working group to the borderland area to carry out a joint investigation with its Chinese counterpart." ${ }^{, 58}$ Beijing this time acted firmly to extract an official apology from Myanmar, which initially refused to give one, claiming as an excuse that it was unclear who was responsible for the errant bombs. The Chinese ambassador to Myanmar, Yang Houlan, lodged an official protest with the Myanmar government and military. Fan Changlong, the vice chairman of the Chinese Central Military Commission, subsequently issued a strong protest to Min Aung Hlaing, commander-in-chief of the Myanmar 
This is the version of the article accepted for publication in Asian Security published by Taylor \& Francis: http://www.tandfonline.com/loi/fasi20

Accepted version downloaded from SOAS Research Online: https://eprints.soas.ac.uk/23597/

Defense Services, calling on Myanmar to investigate the case, apologize and compensate the victims. ${ }^{59}$ Eventually, facing heavy pressure from China Myanmar Foreign Minister U Wunna Maung Lwin government made an official apology, telling his Chinese counterpart, Wang Yi, in a meeting in Beijing on 2 April, "On behalf of the Myanmar government and military, I officially apologize to China and express my deep sympathy to the families of the victims and the injured.",60

\section{Explaining China's Changing Approach toward Myanmar}

How can we make sense of the changes in the Chinese government's responses to the three militarized ethnic conflicts along the Sino-Myanmar border? On the one hand, we observe a more assertive Chinese reaction toward Myanmar regarding the latter's management of its ethnic issues, as clearly illustrated the drastically different responses to the 2009 and 2015 Kokang conflicts. On the other hand, it seems China reacted more strongly to the 2015 Kokang conflict than to the 2013 Kachin conflict. Certainly, it is true that the 2009 Kokang conflict occurred at a time when bilateral relations between Myanmar and China were cordial. Yet, if everything is indeed due to the changes in Myanmar's foreign policy reorientation and China's geostrategic competition with the US, then how do we explain the differences in the Chinese government's reactions to the Kachin and Kokang conflicts after 2011?

\section{The Overseas Chinese Issue \& Domestic Nationalism Signaling}

Since the PRC's founding, one sensitive area in its foreign policy has been how to deal with the large numbers of overseas Chinese in Southeast Asia. ${ }^{61}$ Despite its initial 
This is the version of the article accepted for publication in Asian Security published by Taylor \& Francis: http://www.tandfonline.com/loi/fasi20

Accepted version downloaded from SOAS Research Online: https://eprints.soas.ac.uk/23597/

insistence on granting citizenship to the Chinese diaspora, geopolitical interests centering on the need to improve diplomatic relations with its Southeast Asian neighbors propelled Beijing to rescind that offer. ${ }^{62}$ Instead, it emphasized that local ethnic Chinese should seek citizenship where they reside. However, the issue of appropriate relations between the PRC, which claims to be the only legitimate government of China, and large diaspora communities in Southeast Asia and beyond would continue to be one of the main issues that concerns the Beijing government in its foreign policy making. For example, during the Cold War, Beijing and Taipei competed intensely with each other for the allegiance of the overseas Chinese community in Southeast Asia. ${ }^{63}$ Since the late 1970s, China's economic development also has benefited tremendously from remittances and investment from the diaspora community. ${ }^{64}$ However, amid rising domestic nationalism in China in the 1990s, the issue of its relations with overseas Chinese came back to haunt the Beijing government during a time of crisis. This can be seen in the inaction of the Chinese government toward the atrocities committed toward ethnic Chinese communities in Indonesia in 1998 and the nationalist backlashes against Beijing. ${ }^{65}$ The Jiang Zemin government was heavily criticized by domestic netizens as weak and cowardly for forsaking the lives of innocent overseas Chinese in Indonesia. ${ }^{66}$ Indeed, ever since that time, the Chinese government has increasingly become more vocal in supporting overseas Chinese communities, although it has spent much of its diplomatic energy on PRC citizens residing abroad, as we can see through a few cases of overseas evacuations in East Timor and Libya. ${ }^{67}$

When Myanmar was concerned, it has had its own problems with the sizable overseas Chinese community in the country since achieving independence in 1948. In the 1950s, 
This is the version of the article accepted for publication in Asian Security published by Taylor \& Francis: http://www.tandfonline.com/loi/fasi20

Accepted version downloaded from SOAS Research Online: https://eprints.soas.ac.uk/23597/

there were estimated 400,000 overseas Chinese living in Myanmar, and the PRC used various channels, such as banks, schools, overseas Chinese organizations and the so forth, to influence their political loyalty toward Beijing, which generated fear from the Myanmar side about the Chinese community being a potential "fifth column." "68 After $\mathrm{Ne}$ Win came into power in 1992, ethnic Chinese businesses were targeted for nationalization, which created further resentment toward the Myanmar government. ${ }^{69}$ As we saw earlier, when Beijing exported the Cultural Revolution to the Chinese community in Myanmar, riots targeting the overseas Chinese in cities like Yangon and Mandalay led to a loss of life and property as well as the overall silencing of the community. ${ }^{70}$

In the case of the Kokang, although they are not PRC citizens, they are nonetheless ethnic Han Chinese and long-term residents of Myanmar. However, as we have seen in the 2009 case, their being ethnic Chinese did not generate enough of a response from the Chinese government, and Beijing was willing to let the issue slip by without offering much support for the plight of the Kokang people. However, in the changing context of the geostrategic environment in Southeast Asia and Myanmar's foreign policy reorientation, China has enough interests to publicize the issues of ethnic conflict along its border with Myanmar, which also coincided with significantly more domestic media interest in the situation in Myanmar because of the setbacks suffered by Chinese investment there. Yet, in the Kachin conflict case, because the Jingpo is an ethnic minority group in China, it failed to solicit enough interests or sympathy from the nationalist Chinese netizen, who are mostly Han Chinese. However, this is not the case with Kokang, who are ethnic Han Chinese and claim a long-term connection with the China. One caveat here is that this is not to argue that Chinese involvement in the Kachin peace process is less severe a 
This is the version of the article accepted for publication in Asian Security published by Taylor \& Francis: http://www.tandfonline.com/loi/fasi20

Accepted version downloaded from SOAS Research Online: https://eprints.soas.ac.uk/23597/

response than China demanding an apology from Myanmar in the Kokang case. The only difference is that in the Kokang case in 2015, domestic nationalist mobilization in China occurred which propelled the Chinese government to act tough diplomatically to Myanmar, at least at the symbolic level. However, the Kachin conflict did not solicit as much domestic nationalist interest, and the Chinese involvement in the negotiation process was not widely publicized in Chinese domestic media.

Thus, considering how Peng Jiashen worded his White Paper to strike the Chinese nationalist cord, no wonder it elicited a huge online response. For example, the outspoken nationalist Chinese media Global Times ran a lengthy interview with Peng Jiashen. ${ }^{71}$ In the interview, it specifically emphasized the attachment of Peng to China its lifestyle. By portraying the conflict between the Kokang and the Myanmar government as a form of just resistance, the interview shed a very sympathetic light on Peng and his MNDAA troops. In many online forums, particularly the nationalist and military-oriented ones, there has been comprehensive coverage of the conflict and discussions of how China should respond to the conflict as well as how to deal with the Myanmar government. ${ }^{72}$

Certainly, popular nationalism in China has been constantly growing for the past couple of decades. Even though the Chinese state plays a part in engendering the overall nationalist phenomenon due to its patriotic education and domestic media propaganda, ${ }^{73}$ it is also the case that such popular nationalism has become a double-edged sword and the Chinese government is increasingly under such pressure in its foreign policy making. ${ }^{74}$ Many also contend there is increasingly a congruence of popular nationalism and state nationalism in China, as the state is now more willing to follow the popular 
This is the version of the article accepted for publication in Asian Security published by Taylor \& Francis: http://www.tandfonline.com/loi/fasi20

Accepted version downloaded from SOAS Research Online: https://eprints.soas.ac.uk/23597/

nationalists rather than repressing them. ${ }^{75}$ Thus, the sudden surge of media reports of the plight of the Kokang issue played a crucial role in fostering such public awareness and put Myanmar on the domestic nationalists' horizon. Therefore, the best way to interpret this is to see it as a result of permissive expression by the Chinese government of such information.

As we have discussed earlier, Chinese nationalism has strategically utilized domestic nationalism for its foreign policy purposes. By letting domestic nationalism festering with censoring them, the Chinese government essentially commits itself to stand firm in its diplomatic relations with Myanmar. It makes sense how the combination of geostrategic anxiety on part of the Chinese government as well as the peculiar overseas Chinese issue in its foreign policy making together led to the politicization of the Kokang conflict as a flashpoint for domestic nationalists in 2015.

Since the political opening and reorientation of foreign policy in Myanmar, we have seen bilateral relations between China and Myanmar suffer several major blows. For the most part, China has kept relatively quietly for such setbacks. In order to maintain its existing interests in the country, China has overall downplayed its strategic setbacks in Myanmar. In addition, Beijing is still finding its way on how to deal with the domestic transformation in Myanmar, with ongoing protests at the Letpadaung copper mine and rising anti-Chinese sentiment in general in Myanmar's domestic media. ${ }^{76}$ However, there is not much Beijing can do to influence public opinion in Myanmar in its favor. And the Myanmar government can easily cite the democratic process and audience cost to signal 
This is the version of the article accepted for publication in Asian Security published by Taylor \& Francis: http://www.tandfonline.com/loi/fasi20

Accepted version downloaded from SOAS Research Online: https://eprints.soas.ac.uk/23597/

the credibility of such challenges, thereby side-pass relevant diplomatic pressure. This is the logic of democratic credibility and foreign policy making. ${ }^{77}$

Similar to this logic of democratic credibility and foreign policy making, in the authoritarian context of China, the state maintains relatively strict control of information and media, which means it has a significant amount of leeway in influencing public opinion in the case of nationalist sentiments. We can tell from the drastically increased coverage and the nationalistic focus on the 2015 Kokang situation in comparison with the 2009 conflict. By allowing nationalist anti-Myanmar sentiments to fester online, Beijing has essentially committed itself to a much tougher stance toward Myanmar, and it can more credibly signal to Myanmar its true intentions by citing such nationalist pressure that Beijing is significantly upset at how the Myanmar government has handled ethnic politics along the border. This is perhaps one factor that led to the eventual apology issued by the Myanmar government.

\section{Conclusion}

The militarized ethnic conflicts along the Sino-Myanmar borderland area and the responses they generated from the Chinese government toward the Myanmar government have offered an excellent opportunity to examine the changing dynamics in relations between the two countries. As we have seen in the comparative case studies presented in the paper, the strategic uncertainty created by the sudden changes in Myanmar's foreign relations with the United States highlighted the urgency for Beijing to effectively communicate its resolve to protect China's national interests in Myanmar as well as to demonstrate its capacity to monitor Myanmar's domestic ethnic politics along the border. 
This is the version of the article accepted for publication in Asian Security published by Taylor \& Francis: http://www.tandfonline.com/loi/fasi20

Accepted version downloaded from SOAS Research Online: https://eprints.soas.ac.uk/23597/

It argues that how specific nationalist items, such as the issue of overseas Chinese, can be effectively mobilized by Beijing to signal its resolve with regard to its concern of border security between the two countries. By allowing domestic nationalist sentiment toward Myanmar to build, the Chinese government effectively bound itself to act tough toward its southern neighbor. Through such comparative analysis, the paper thus presented a consistent portrayal of the changes in China's diplomatic approach toward its southern neighbor.

Having said that, one also need to note the possibility that the leadership change in China when Xi Jinping came to power in 2012 could have played a role in China's tougher positions toward Myanmar. Indeed, Xi's government has been credited with being more aggressive diplomatically in disputes with China's neighbors, especially regarding territorial disputes in the South China Sea. ${ }^{78}$ In fact, Xi's increasingly aggressive approach in foreign relations are overlapped with a push for more strident nationalism domestically, for example in his government's promotion of the "Chinese Dream" campaign (zhong guo meng) ${ }^{79}$ This is indeed consistent with the analysis presented in the paper that nationalism played a crucial role in Beijing's foreign policy signal toward Myanmar. As we have seen, the Kokang issue illustrated the special place the overseas Chinese issue can play in generating domestic nationalist pressure on the Chinese government, especially when it was publicized and politicized. Ever since the Kokang conflict in 2015, there has been high amount of awareness of the situation of overseas Chinese in Myanmar. This means future bilateral relations between the two countries could be further complicated by the rising public awareness and interests shown by domestic nationalist netizens toward Myanmar. Because Myanmar has now entered the 
This is the version of the article accepted for publication in Asian Security published by Taylor \& Francis: http://www.tandfonline.com/loi/fasi20

Accepted version downloaded from SOAS Research Online: https://eprints.soas.ac.uk/23597/

radar of domestic nationalists, it means that future dealings between the two countries

would be under closer scrutiny, and would introduce more complexities to how China

and Myanmar figure out their bilateral relations in a fast-changing geopolitical context in

Southeast Asia.

\section{Notes}

${ }^{1}$ Stephen G. Brooks and William C. Wohlforth, "The Rise and Fall of the Great Powers in the Twenty-First Century: China's Rise and the Fate of America's Global Position," International Security 40, no. 3 (January 1, 2016): 7-53; Thomas Christensen, The China Challenge: Shaping the Choices of a Rising Power, 1 edition (New York: W. W. Norton \& Company, 2015); Hugh White, The China Choice: Why We Should Share Power, Reprint edition (Oxford, United Kingdom: Oxford University Press, 2013); David C. Kang, China Rising: Peace, Power, and Order in East Asia (New York: Columbia University Press, 2009). ${ }^{2}$ Darren J. Lim and Zack Cooper, "Reassessing Hedging: The Logic of Alignment in East Asia," Security Studies 24, no. 4 (October 2, 2015): 696-727; Renato Cruz de Castro, "The US-Philippine Alliance: An Evolving Hedge against an Emerging China Challenge," Contemporary Southeast Asia: A Journal of International and Strategic Affairs 31, no. 3 (2009): 399-423; Adam P. Liff and G. John Ikenberry, "Racing toward Tragedy?: China's Rise, Military Competition in the Asia Pacific, and the Security Dilemma," International Security 39, no. 2 (October 1, 2014): 52-91; Cheng-Chwee Kuik, "The Essence of Hedging: Malaysia and Singapore's Response to a Rising China," Contemporary Southeast Asia: A Journal of International and Strategic Affairs 30, no. 2 (2008): 159-85; Steve Chan, Looking for Balance: China, the United States, and Power Balancing in East Asia (Stanford, California: Stanford University Press, 2013); Bruce Gilley and Andrew O'Neil, eds., Middle Powers and the Rise of China (Washington, DC: Georgetown University Press, 2014).

${ }^{3}$ In this paper, I use Myanmar instead of Burma as the country's name unless in direct quotes. Similarly, I adopt the new spellings of place names such as Yangon instead of Rangoon.

${ }^{4}$ Enze Han, "Borderland Ethnic Politics and Changing Sino-Myanmar Relations," in War and Peace in the Borderlands of Myanmar: The Kachin Ceasefire, 1994-2011, ed. Mandy Sadan (Copenhagen: NIAS Press, 2016).

${ }^{5}$ David I. Steinberg, "Editorial On China-Myanmar Relations," Journal of Current Southeast Asian Affairs 31, no. 1 (January 2012): 3-6.

${ }^{6}$ For some policy-oriented analyses on Sino-Myanmar relations, please see Yun Sun, "China and the Changing Myanmar," Journal of Current Southeast Asian Affairs 31, no. 4 (2012): 51; Yun Sun, "China's Strategic Misjudgement on Myanmar," Journal of Current Southeast Asian Affairs 31, no. 1 (2012): 73.

${ }^{7}$ Robert L. Rothstein, Alliances and Small Powers (New York, Columbia University Press, 1968); David Vital, The Inequality of States: A Study of He Small Power in International Relations. (Oxford, Clarendon P, 1967); August Schou and Arne Olav Brundtland, eds., Small States in International Relations (John Wiley \& Sons Inc, 1971).

${ }^{8}$ Evelyn Goh, "Great Powers and Hierarchical Order in Southeast Asia: Analyzing Regional Security Strategies," International Security 32, no. 3 (2007): 113-57; Denny Roy, "Southeast Asia and China: Balancing or Bandwagoning?," Contemporary Southeast Asia: A Journal of International and Strategic Affairs 27, no. 2 (2005): 305-22; Kuik, "The Essence of Hedging"; Rosemary Foot, "Chinese Strategies in A US-Hegemonic Global Order: Accommodating and Hedging," International Affairs 82, no. 1 (January 1, 2006): 77-94.

${ }^{9}$ Cheng-Chwee Kuik, "How Do Weaker States Hedge? Unpacking ASEAN States' Alignment Behavior towards China," Journal of Contemporary China 25, no. 100 (July 3, 2016): 502.

${ }^{10}$ Jessica Chen Weiss, Powerful Patriots: Nationalist Protest in China's Foreign Relations (New York, NY: Oxford University Press, 2014). 
This is the version of the article accepted for publication in Asian Security published by Taylor \& Francis: http://www.tandfonline.com/loi/fasi20

Accepted version downloaded from SOAS Research Online: https://eprints.soas.ac.uk/23597/

${ }^{11}$ Jessica Chen Weiss, "Authoritarian Signaling, Mass Audiences, and Nationalist Protest in China," International Organization 67, no. 01 (January 2013): 2.

${ }^{12}$ Baobo in Chinese, meaning kinship bilateral relations.

${ }^{13}$ Maung Aung Myoe, In the Name of Pauk-Phaw: Myanmar's China Policy since 1948 (Singapore: Institute of Southeast Asian Studies ; London, 2011), 13.

${ }^{14}$ Richard Michael Gibson and Wen H. Chen, The Secret Army: Chiang Kai-Shek and the Drug Warlords of the Golden Triangle (Singapore: Wiley, 2011).

${ }^{15}$ Bertil Lintner, The Rise and Fall of the Communist Party of Burma (CPB), 6 (SEAP Publications, 1990), 19.

${ }^{16}$ Robert H. Taylor, Foreign and Domestic Consequences of the KMT Intervention in Burma (Ithaca, NY: Southeast Asia Program, Dept of Asian Studies, Cornell University, 1973).

${ }^{17}$ Aung Myoe, In the Name of Pauk-Phaw, 23.

${ }^{18}$ Ibid., 39.

${ }^{19}$ See for example, Robert A. Holmes, "Burma's Foreign Policy Toward China Since 1962," Pacific Affairs 45, no. 2 (1972): 240-54.

${ }^{20}$ Beijing's open support for the BCP obviously was motivated by various reasons. Another factor is the overall radicalization of China's foreign policy during the Cultural Revolution as China deemed itself the champion for Third World revolutions.

${ }^{21}$ Lintner, The Rise and Fall of the Communist Party of Burma (CPB), 26.

${ }^{22}$ Aung Myoe, In the Name of Pauk-Phaw, 80-82.

${ }^{23}$ See Martin Smith, Burma: Insurgency and the Politics of Ethnic Conflict (Zed Books, 1999); Ashley South, Ethnic Politics in Burma: States of Conflict, 1 edition (London; New York: Routledge, 2008).

${ }^{24}$ Aung Myoe, In the Name of Pauk-Phaw, 110. Juergen Haacke, "The Nature and Management of Myanmar's Alignment with China: The SLORC/SPDC Years," Journal of current Southeast Asian affairs 30, no. 2 (2011): 105.

${ }^{25}$ The Deyapin incident occurred in May 2003, when the military government killed many supporters of the National League for Democracy. Please see http://www.humanrights.asia/resources/journalsmagazines/article2/0206/the-depayin-massacre-a-crime-against-humanity-and-its-effect-on-nationalreconciliation

${ }^{26}$ David I. Steinberg and Hongwei Fan, Modern China-Myanmar Relations: Dilemmas of Mutual Dependence, Nordic Institute of Asian Studies Monograph Series ; No. 121 (Copenhagen: NIAS Press, 2012), 331-32.

${ }^{27}$ Lee Jones, "The Political Economy of Myanmar's Transition," Journal of Contemporary Asia 44, no. 1 (February 1, 2014): 144.

${ }^{28}$ Jalal Alamgir, "Myanmar's Foreign Trade and Its Political Consequences," Asian Survey 48, no. 6 (2008): 986.

${ }^{29}$ Aung Myoe, In the Name of Pauk-Phaw, 152-53.

${ }^{30}$ Ibid.

${ }^{31}$ For example, see Gurpreet S. Khurana, "China's 'String of Pearls' in the Indian Ocean and Its Security Implications," Strategic Analysis 32, no. 1 (February 27, 2008): 1-39; Alex Vines, "Mesmerised by Chinese String of Pearls Theory," The World Today 68, no. 2 (2012): 33-34.

${ }^{32}$ Naypyidaw is Myanmar's new capital, which the military government established in 2005.

${ }^{33}$ Stephanie Shannon and Nicholas Farrelly, "Whither China's Myanmar Stranglehold?," in ISEAS Perspective, Books and Monographs (ISEAS-Yusof Ishak Institute, 2014).

${ }^{34} \mathrm{http} / / / \mathrm{www}$. atimes.com/atimes/Southeast_Asia/SEA-01-140814.html

${ }^{35}$ Yun Sun, "China, the United States and the Kachin Conflict," Great Powers and The Changing Myanmar Issue Brief (Washington, DC: Stimson Center, 2014).

${ }^{36}$ Interviews with officials at the Chinese Embassy in Yangon, Myanmar, summer 2014. The reason why the Yunnan province features prominently in Chinese diplomacy toward Myanmar is because this is the province that borders directly with Myanmar, and previously the Chinese government delegated part of the foreign policy consultation toward Myanmar at the Yunnan provincial level, especially regarding trade and other economic relations.

${ }^{37}$ Yun Sun, "China, Myanmar Face Myitsone Dam Truths," Asia Times Online, February 19, 2014, http://www.atimes.com/atimes/Southeast_Asia/SEA-01-190214.html. 
This is the version of the article accepted for publication in Asian Security published by Taylor \& Francis: http://www.tandfonline.com/loi/fasi20

Accepted version downloaded from SOAS Research Online: https://eprints.soas.ac.uk/23597/

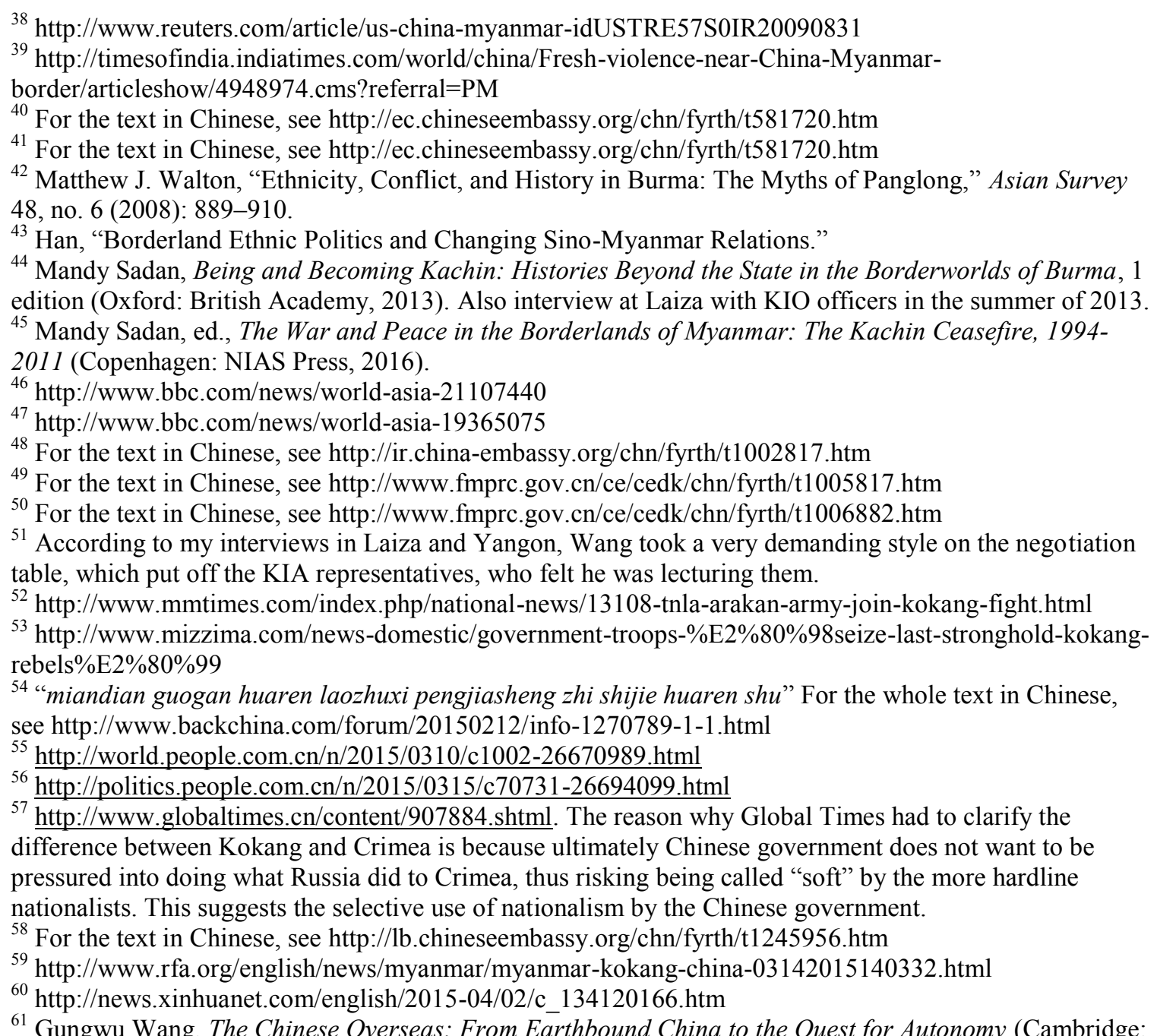

${ }^{61}$ Gungwu Wang, The Chinese Overseas: From Earthbound China to the Quest for Autonomy (Cambridge: Harvard University Press, 2002); Wang Gungwu, China and the Chinese Overseas (Marshall Cavendish Academic, 1991); George William Skinner, Chinese Society in Thailand An Analytical History, ACLS Humanities E-Book (Ithaca, NY: Cornell University Press, 1957).

${ }^{62}$ Donald Earl Willmott, The National Status of the Chinese in Indonesia, 1900-1958., Rev. ed., Monograph Series (Cornell University. Modern Indonesia Project) (Ithaca, NY: Cornell University Press, 1961); Leo Suryadinata, The Making of Southeast Asian Nations: State, Ethnicity, Indigenism and Citizenship (Singapore: World Scientific, 2015, 2015).

${ }^{63}$ Aranya Siriphon, "The Qiaoban, The PRC Influence and Nationalist Chinese in Northern Thai Borderland," International Journal of Asian Studies 13, no. 1 (January 1, 2016): 1-17.

${ }^{64}$ Paul J. Bolt, "Looking to the Diaspora: The Overseas Chinese and China's Economic Development, 1978-1994," Diaspora: A Journal of Transnational Studies 5, no. 3 (1996): 467-96.

${ }^{65}$ Jemma Purdey, "Political Change Reopening the Asimilasi vs Integrasi Debate: Ethnic Chinese Identity in Post-Suharto Indonesia," Asian Ethnicity 4, no. 3 (October 1, 2003): 421-37; Christopher Rene Hughes, "Nationalism in Chinese Cyberspace," Cambridge Review of International Affairs 13, no. 2 (March 1, 2000): 195-209.

${ }^{66}$ Daojiong Zha, "China and the May 1998 Riots of Indonesia: Exploring the Issues," The Pacific Review 13, no. 4 (January 1, 2000): 557-75; Xu Wu, Chinese Cyber Nationalism: Evolution, Characteristics, and Implications (Lanham: Lexington Books, 2007).

${ }^{67}$ Shaio H. Zerba, "China's Libya Evacuation Operation: A New Diplomatic Imperative-Overseas Citizen Protection,” Journal of Contemporary China 23, no. 90 (November 2, 2014): 1093-1112. 
This is the version of the article accepted for publication in Asian Security published by Taylor \& Francis: http://www.tandfonline.com/loi/fasi20

Accepted version downloaded from SOAS Research Online: https://eprints.soas.ac.uk/23597/

${ }^{68}$ Hugh Tinker, The Union of Burma: A Study of The First Years of Independence (London: Oxford University Press, 1967).

${ }^{69}$ Robert Taylor, General Ne Win: A Political Biography (Singapore: Institute of Southeast Asian Studies, 2015).

${ }^{70}$ Hongwei Fan, "The 1967 Anti-Chinese Riots in Burma and Sino-Burmese Relations," Journal of Southeast Asian Studies 43, no. 2 (June 2012): 234-56.

${ }^{71} \mathrm{http}: / /$ world.huanqiu.com/exclusive/2014-12/5307556.html

${ }^{72}$ For example, the 2015 Kokang conflict was featured significantly on tiexuewang (Iron Blood Network), which is one of the most vocal Chinese nationalist/military online forum. See http://bbs.tiexue.net/post2_8506893_1.html

${ }^{73}$ Suisheng Zhao, "A State-Led Nationalism: The Patriotic Education Campaign in Post-Tiananmen China," Communist and Post-Communist Studies 31, no. 3 (September 1998): 287-302; Zheng Wang, "National Humiliation, History Education, and the Politics of Historical Memory: Patriotic Education Campaign in China," International Studies Quarterly 52, no. 4 (December 1, 2008): 783-806.

${ }^{74}$ Christopher Hughes, "Reclassifying Chinese Nationalism: The Geopolitik Turn," Journal of Contemporary China 20, no. 71 (September 1, 2011): 601-20; Peter Hays Gries, China's New Nationalism: Pride, Politics, and Diplomacy (Berkeley: University of California Press, 2004), https://library.princeton.edu/resolve/lookup?url=http://www.jstor.org/stable/10.1525/j.ctt1pq06f.

${ }^{75}$ Suisheng Zhao, "Foreign Policy Implications of Chinese Nationalism Revisited: The Strident Turn," Journal of Contemporary China 22, no. 82 (July 1, 2013): 535-53.

${ }^{76}$ Min Zin, "Burmese Attitude toward Chinese: Portrayal of the Chinese in Contemporary Cultural and Media Works," Journal of Current Southeast Asian Affairs 31, no. 1 (January 1, 2012): 115-31.

${ }_{77}$ James D. Fearon, "Domestic Political Audiences and the Escalation of International Disputes," The American Political Science Review 88, no. 3 (September 1, 1994): 577-92. Kenneth A. Schultz, "Looking for Audience Costs," Journal of Conflict Resolution 45, no. 1 (January 2, 2001): 32-60.

${ }^{78}$ Jean-Marc Blanchard, "The People's Republic of China Leadership Transition and Its External Relations: Still Searching for Definitive Answers," Journal of Chinese Political Science 20, no. 1 (March 2015): 116; Irene Chan and Mingjiang Li, "New Chinese Leadership, New Policy in the South China Sea Dispute?," Journal of Chinese Political Science 20, no. 1 (March 2015): 35-50.

${ }^{79}$ William Callahan, China Dreams: 20 Visions of the Future, 1 edition (Oxford ; New York: OUP USA, 2013). 